\title{
Metastatic Chordoma
}

National Cancer Institute

\section{Source}

National Cancer Institute. Metastatic Chordoma. NCI Thesaurus. Code C153323.

A chordoma that has spread from its original site of growth to other anatomic sites. 